\title{
Antihypertensive properties of tilapia (Oreochromis spp.) frame and skin enzymatic protein hydrolysates
}

\author{
Hsin-Chieh Lin ${ }^{\mathrm{a}}$, Adeola M. Alashi $\mathbb{1}^{\mathrm{b}}$, Rotimi E. Aluko $\mathbb{1}^{\mathrm{b}}$, Bonnie Sun Pan ${ }^{\mathrm{a}}$ and Yu-Wei Chang ${ }^{\mathrm{a}}$

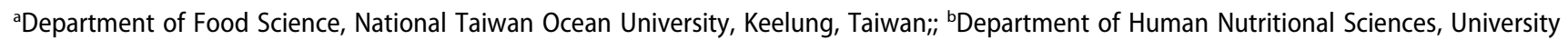 \\ of Manitoba, Winnipeg, MB, Canada
}

\begin{abstract}
Proteins from tilapia frame and skin can potentially be precursors of antihypertensive peptides according to the result of BIOPEP analyses. The aim was to generate peptides with inhibitory effects against angiotensin-converting enzyme (ACE) and renin from tilapia frame and skin protein isolates (FPI and SPI). The most active hydrolysate was then tested for blood pressurelowering ability in spontaneously hypertensive rats (SHRs). Tilapia frame and skin protein hydrolysates (FPHs and SPHs) were respectively produced from FPI and SPI hydrolysis using pepsin, papain, or bromelain. The ACE-inhibitory activities of tilapia protein hydrolysates with varying degree of hydrolysis $(\mathrm{DH})$ were evaluated. In order to enhance the activity, the hydrolysate was fractionated into four fractions $(<1 \mathrm{kDa}, 1-3 \mathrm{kDa}, 3-5 \mathrm{kDa}$, and 5-10 $\mathrm{kDa}$ ) and the one with the greatest ability to inhibit in vitro ACE and renin activities was subjected to oral administration (100 mg/kg body weight) to SHRs. Systolic and diastolic blood pressure (SBP and DBP), mean arterial pressure (MAP), and heart rates (HR) were subsequently measured within $24 \mathrm{~h}$. The pepsin-hydrolyzed FPH (FPHPe) with the highest DH (23\%) possessed the strongest ACE-inhibitory activity $\left(\mathrm{IC}_{50}: 0.57 \mathrm{mg} / \mathrm{mL}\right.$ ). Its $<1 \mathrm{kDa}$ ultrafiltration fraction (FPHPe1) suppressed both ACE $\left(\mathrm{IC}_{50}: 0.41 \mathrm{mg} / \mathrm{mL}\right)$ and renin activities more effectively than larger peptides. In addition, FPHPe1 significantly $(p<0.05)$ reduced SBP (maximum $-33 \mathrm{mmHg}$ ), DBP (maximum $-24 \mathrm{mmHg}$ ), MAP (maximum $-28 \mathrm{mmHg}$ ), and HR (maximum -58 beats) in SHRs. FPHPe1 showed both in vitro and in vivo antihypertensive effects, which suggest tilapia processing coproducts may be valuable protein raw materials for producing antihypertensive peptides.
\end{abstract}

\section{ARTICLE HISTORY}

Received 7 April 2017

Accepted 4 October 2017

\section{KEYWORDS}

Tilapia; frame protein hydrolysate; skin protein hydrolysate; angiotensin I-converting enzyme; renin; spontaneously hypertensive rats

\section{Introduction}

Tilapia is one of the most important and widely cultured food fish worldwide. Global aquaculture production of tilapia increased from 2 million tons in 2005 to 5.3 million tons in 2014 with an annual production growth around $10 \%$ [1]. During tilapia filleting, large quantities of byproducts including tilapia head, frame, and skin, which may contain $16-80 \%$ protein content are underutilized $[2,3]$. As value-added usage of fish by-products has drawn attention, recovery or alteration of protein structure by enzyme technology has become a feasible choice [4].

Studies have revealed that hydrolysates or peptides derived from tilapia protein possess physiological functions. Enzymatic hydrolysates of tilapia muscle containing nearly $40 \%$ hydrophobic amino acids [5] showed antioxidant [6] and antihypertensive properties [7]. The preventive effect of tilapia hydrolysate against oxidative damage in HepG2 cells and the protective ability against DNA damage have also been reported [8]. In addition to the antioxidant and angiotensin converting enzyme (ACE)-inhibitory activities of tilapia frame [9] and skin gelatin [10] hydrolysates, tilapia protein hydrolysates also exhibited antibacterial activities [11]. Peptides from tilapia by-products displayed various biological activities as well. A calcium-binding peptide isolated from tilapia scale protein hydrolysate was discovered to prevent calcium deficiency with improved calcium bioavailability in rats [12].

The conventional approach of screening of bioactive peptides from different substrates is an inefficient process because it involves using empirical methods to select appropriate proteases and requires experimental evaluation of each one for in vitro activities. Due to advances in bioinformatics, this laborious process can be simplified by using in silico tools such as the BIOPEP database and computation program [13]. Such in silico methods have been widely applied for analyzing potential activities of food proteins after 
enzymatic digestion. For example, the ACE-inhibitory activities of protein hydrolysates from chickpea [14] and crude barley [15] were reported using this in silico approach. A similar approach was used to show that whey protein hydrolysate possessed both ACE-inhibitory and antioxidative effects [16]. Prolyl endopeptidase (PEP) inhibitory peptides were found to be present in bovine and porcine meat [17]. In our previous research work, some muscle proteins including myosin heavy chain (1523 amino acids) and alphaactin (353 amino acids) were identified as the major proteins in tilapia (Oreochromis spp.) frame protein isolate (FPI), whereas skin protein isolate (SPI) was mostly composed of two types of collagen alpha chains (1450 and 1355 amino acids) [2]. Preliminary screening of encrypted bioactive peptides, identified based on the primary sequence of tilapia proteins, indicated that most of the peptides were ACE inhibitors. In addition, PEP-inhibitory peptides, which are related to antiamnesic activity were shown to be mainly present in SPI instead of FPI.

Renin and ACE are the two pivotal enzymes that regulate the renin-angiotensin system (RAS), which plays a crucial role in the pathogenesis of hypertension [18]. Angiotensinogen released from liver is cleaved by renin and generates angiotensin I, which is subsequently converted to angiotensin II by the action of ACE. Angiotensin II is a potent vasoconstrictor, which results in blood pressure increase. Thus, multifunctional peptides with simultaneous inhibition of renin and ACE activities provide a more efficient RAS regulation compared to specific single enzyme inhibitors [19].

Although the application of bioactive peptide database is efficient in choosing appropriate proteases, overlooking the interference factors associated with in vitro digestion could lead to discordance between in silico and in vitro methods [20]. In silico methods are used initially to assess the effectiveness of the enzyme-produced bioactive peptides. Further in vitro or in vivo studies are also required. After identification of the proteins from tilapia processing co-product using proteomic techniques, analysis of bioactive peptides based on the protein sequences was executed using BIOPEP. The in silico data revealed numerous ACE-inhibitory peptides within the primary structure of tilapia proteins. In this study, three commercial enzymes pepsin, papain, and bromelain were used to hydrolyze the proteins from tilapia processing co-products. Therefore, the objective of this work was to determine the in vitro inhibition of $\mathrm{ACE}$ and renin activities by the enzymatic hydrolysates of tilapia frame and skin proteins. The most active hydrolysate was then tested for blood pressure-reducing activity through oral administration to spontaneously hypertensive rats (SHR).

\section{Materials and methods}

\section{Materials}

Tilapia frame and skin were acquired from a local sea food processing plant (Fortune Life Company, Kaohsiung, Taiwan). Pepsin (from porcine gastric mucosa), papain (from Carica papaya) and bromelain (from pineapple stem) were purchased from Sigma-Aldrich (St. Louis, MO, USA). ACE (from rabbit lung) and its substrate, $\mathrm{N}$-(3-[2-furyl]acryloyl)-phenylalanylglycylglycine (FAPGG) were also obtained from Sigma-Aldrich. Human recombinant Renin Inhibitor Screening Assay Kit was purchased from Cayman Chemicals (Ann Arbor, MI, USA). Other chemicals and reagents used were of analytical grade.

\section{Production of tilapia protein isolate}

Preparation of tilapia frame protein isolate (FPI) and skin protein isolate (SPI) were based on the method of [7] and [21], respectively, with some modifications. Briefly, the tilapia frame was cut into pieces, homogenized with deionized water $(1: 9 \mathrm{w} / \mathrm{v})$, the homogenate adjusted to $\mathrm{pH} 12$ and then stirred at $4^{\circ} \mathrm{C}$ for $30 \mathrm{~min}$. After filtration through a $10 \mu \mathrm{m}$ mesh metal filter, the homogenate was centrifuged $\left(8000 \mathrm{~g}, 4^{\circ} \mathrm{C}\right)$ for $10 \mathrm{~min}$, the supernatant filtered through cheesecloth and adjusted to $\mathrm{pH} 5.5$ to precipitate the proteins. The precipitate collected after another centrifugation round was lyophilized and labeled as frame protein isolate (FPI). Sliced tilapia skin was soaked in 95\% ethanol (skin:ethanol, 1:9 w/ v) for $48 \mathrm{~h}$ with a change in solvent after $24 \mathrm{~h}$ in order to remove lipid materials The defatted skin was then soaked for $6 \mathrm{~h}$ in $0.1 \mathrm{M} \mathrm{NaOH}$ (skin: $\mathrm{NaOH}, 1: 9 \mathrm{w} / \mathrm{v}$ ) followed by homogenization with deionized water (skin: $\mathrm{NaOH}, 1: 9$ w/v) and adjusted to $\mathrm{pH}$ 2. The homogenate was stirred at $4^{\circ} \mathrm{C}$ for $48 \mathrm{~h}$ and then centrifuged $\left(8000 \mathrm{~g}, 4^{\circ} \mathrm{C}\right)$ for $20 \mathrm{~min}$. The resultant supernatant was adjusted to $\mathrm{pH} 7$, centrifuged and the precipitate lyophilized as skin protein isolate (SPI). Both FPI and SPI powder were each stored at $-20^{\circ} \mathrm{C}$ until use. 


\section{BIOPEP analysis of bioactive peptides from tilapia proteins}

The assessment of potential antihypertensive and antiamnesic peptides from tilapia proteins was carried out using BIOPEP [22] analysis. Sequences of identified tilapia proteins were obtained from NCBI database as described previously [2]. Proteins were subjected to in silico papain or bromelain proteolysis to generate peptides with specific activities, which were then searched for and the numbers of ACE-inhibitory peptides calculated. In addition, pepsin, trypsin, and chymotrypsin $\mathrm{A}$ or $\mathrm{C}$ were applied simultaneously to cleave tilapia protein sequences in order to mimic protein digestion in the gastrointestinal tract.

\section{Enzymatic hydrolysis}

Hydrolysis of FPI and SPI was conducted based on the method of Shamloo et al. [23]. FPI or SPI were homogenized with deionized water (protein isolate/water, $1: 9 \mathrm{w} / \mathrm{v}$ ) and adjusted to the optimal $\mathrm{pH}$ and temperature for each enzyme (pepsin: $37^{\circ} \mathrm{C}, \mathrm{pH}$ 2; bromelain: $50^{\circ} \mathrm{C}, \mathrm{pH} 7$; papain: $55^{\circ} \mathrm{C}, \mathrm{pH}$ 7). The hydrolysis was started by adding $1 \%$ (enzyme/substrate, w/w) protease. After 4-h hydrolysis of FPI or SPI using a single enzyme (pepsin, papain or bromelain), the digest was placed in a $95^{\circ} \mathrm{C}$ water bath for $15 \mathrm{~min}$ to inactivate the enzyme and then cooled to room temperature. The cooled digest was then centrifuged $\left(10,000 \mathrm{~g}, 4^{\circ} \mathrm{C}\right)$ for $20 \mathrm{~min}$ and the supernatant was lyophilized and stored at $-20^{\circ} \mathrm{C}$ as the frame or skin protein hydrolysate. Frame protein hydrolysates (FPHs) generated by pepsin, papain, or bromelain were designated as FPHPe, FPHPa, and FPHBr, respectively. Similarly, skin protein hydrolysates (SPHs) prepared using pepsin, papain, and bromelain individually were designated as SPHPe, SPHPa, and SPHBr, respectively. The protein contents of protein isolates and hydrolysates were determined using the modified Lowry method [24]. In the following bioactivity assays and rat study, the concentration $(\mathrm{mg} / \mathrm{mL})$ of protein hydrolysates applied reptresents the final protein concentration of samples.

\section{Degree of hydrolysis}

The ortho-phthalaldehyde (OPA) method described by Charoenphun et al. [25] was used to estimate $\mathrm{DH}$ with some modifications. The freshly prepared reagent consisted of $6 \mathrm{mM}$ OPA (dissolved in metha$\mathrm{nol})$ and $0.2 \%(\mathrm{v} / \mathrm{v}) 2$-mercaptoethanol in $50 \mathrm{mM}$ sodium tetraborate containing $1 \%(\mathrm{w} / \mathrm{v})$ SDS. A $200-\mu \mathrm{L}$ aliquot of the OPA reagent was added to
$5 \mu \mathrm{L}$ of standard (gly-gly-gly) or protein hydrolysate and mixed. The mixture was incubated for $100 \mathrm{~s}$ at room temperature and the absorbance was measured at $340 \mathrm{~nm}$ using multiplate reader (Multiskan Go, Thermo Fisher Scientific, Waltham, MA, USA). Acidic hydrolysis using $6 \mathrm{~N} \mathrm{HCl}$ at $110^{\circ} \mathrm{C}$ for $24 \mathrm{~h}$ was used to determine the total amount of primary amino groups. DH was defined as the percentage of cleaved peptide bonds as follows:

$$
\mathrm{DH}(\%)=\frac{\left(\mathrm{NH}_{2}\right)_{\mathrm{tx}}-\left(\mathrm{NH}_{2}\right)_{\mathrm{t} 0}}{\left(\mathrm{NH}_{2}\right)_{\mathrm{total}}-\left(\mathrm{NH}_{2}\right)_{\mathrm{t} 0}} \times 100(\%)
$$

where $\left(\mathrm{NH}_{2}\right)_{\mathrm{tx}}$ is the number of free amino groups at $\mathrm{X}$ min and $\left(\mathrm{NH}_{2}\right)_{\text {total }}$ is the total number of amino groups. $\left(\mathrm{NH}_{2}\right)_{\mathrm{t} 0}$ represents the amount of free amino groups at 0 min of hydrolysis.

\section{Sodium dodecyl sulfate polyacrylamide gel electrophoresis (SDS-PAGE) analysis}

Electrophoresis patterns of protein isolates and hydrolysates were analyzed using SDS-PAGE [26] with $4 \%$ stacking gel and $18 \%$ resolving gel. FPI, SPI, and their hydrolysates were dissolved in sample buffer $(0.5 \mathrm{M}$ Tris- $\mathrm{HCl} \mathrm{pH} 6.8$, glycerol, $10 \%$ SDS, w/v, 0.5\% bromophenol blue, w/v, $\beta$-mercaptoethanol) at a concentration of $4 \mathrm{mg} / \mathrm{mL}$ and denatured at $95^{\circ} \mathrm{C}$ for $5 \mathrm{~min}$. The loading volume was $10 \mu \mathrm{L}$ in all sample lanes. After separation, the gel was stained with Coomassie Brilliant Blue R-250 for 30 min and then destained using water/ methanol/acetic acid (7/2/1, v/v/v) followed by being scanned with E-Box VX5 (Vilber Lourmat, Paris, France). The standard protein marker (broad range molecular weight, Bio-Rad, Hercules, CA, USA) was used to construct a standard curve $(10-250 \mathrm{kDa})$ for the MW estimation.

\section{Fractionation of pepsin-generated tilapia frame protein hydrolysate (FPHPe)}

The FPHPe was further fractionated by ultrafiltration using an Amicon stirred ultrafiltration cell (Millipore Corporation, Bedford, MA, USA) with 1, 3, 5, and 10 $\mathrm{kDa}$ molecular weight cut-off (MWCO) membranes. Fractions with different MW cut-offs $(<1 \mathrm{kDa}, 1-3$ $\mathrm{kDa}, 3-5 \mathrm{kDa}$, and 5-10 kDa) were collected as previously described [27], lyophilized and stored at $-20^{\circ} \mathrm{C}$ until use. The yields of hydrolysate fractions were calculated based on the dry weight of permeate against the dry weight of protein hydrolysate used for ultrafiltration. 


\section{ACE inhibition assay}

The effect of hydrolysates on inhibition of in vitro ACE activity was measured according to the method reported by Udenigwe et al. [28] with some modifications. A $0.5 \mathrm{mM} \mathrm{N}$-[3-(2-furyl) acryloyl]-L-phenylalanyl glycyl glycine (FAPGG) was prepared in $50 \mathrm{mM}$ Tris- $\mathrm{HCl}$ buffer to contain $0.3 \mathrm{M} \mathrm{NaCl}$ and adjusted to $\mathrm{pH}$ 7.5. The FAPGG was used as substrate and samples were dissolved in the same buffer as the FAPGG. When conducting assays, $170 \mu \mathrm{L}$ of $0.5 \mathrm{mM}$ FAPGG was mixed with $10 \mu \mathrm{L}$ ACE $(0.5 \mathrm{U} / \mathrm{mL}$, final activity of $25 \mathrm{mU})$ and $20-\mu \mathrm{L}$ sample. The rate of decrease in absorbance at $345 \mathrm{~nm}$ was recorded for $30 \mathrm{~min}$ at $37^{\circ} \mathrm{C}$ using Synergy $\mathrm{H} 4$ microplate reader (BioTek Instruments, Winooski, VT, USA). The buffer was used instead of sample solutions for the control (uninhibited reaction). ACE activity was expressed as the rate of reaction $(\Delta \mathrm{A} / \mathrm{min})$ and inhibitory activity was calculated as:

$$
\begin{gathered}
\operatorname{ACE} \text { inhibition }(\%)=\left[1-\Delta A \min _{(\text {sample })}^{-1} / \Delta A \min _{(\text {control })}^{-1}\right] \\
\times 100(\%)
\end{gathered}
$$

Where $\Delta \mathrm{A} \mathrm{min}{ }^{-1}$ (sample) and $\Delta \mathrm{A} \mathrm{min}{ }^{-1}$ (control) represent $\mathrm{ACE}$ activity in the presence and absence of the peptides, respectively.

\section{Renin inhibition assay}

In vitro inhibition of human recombinant renin was conducted using Renin Inhibitor Screening Assay Kit according to the method described by Girgih et al. [29]. Peptide fractions were dissolved in Tris- $\mathrm{HCl}$ buffer (50 mM, pH 8) containing $100 \mathrm{mM} \mathrm{NaCl}$. The buffer was pre-warmed to $37^{\circ} \mathrm{C}$ prior to the reaction. Before the reaction, 1) $20 \mu \mathrm{L}$ substrate, $151 \mu \mathrm{L}$ assay buffer, and $19 \mu \mathrm{L}$ Tris- $\mathrm{HCl}$ buffer were added to the background wells; 2) $20 \mu \mathrm{L}$ substrate, $141 \mu \mathrm{L}$ assay buffer, and $19 \mu \mathrm{L}$ Tris- $\mathrm{HCl}$ buffer were added to the control wells; and 3) $20 \mu \mathrm{L}$ substrate, $141 \mu \mathrm{L}$ assay buffer, and $19 \mu \mathrm{L}$ sample were added to the inhibitor wells. The reaction was initiated by adding $10 \mu \mathrm{L}$ renin to the control and sample wells. The microplate was shaken for $10 \mathrm{~s}$ to mix and incubated at $37^{\circ} \mathrm{C}$ for $15 \mathrm{~min}$, and the fluorescence intensity (FI) was then recorded at the excitation and emission wavelengths of $340 \mathrm{~nm}$ and $490 \mathrm{~nm}$, respectively, on a fluorometric microplate reader (Spectra MAX Gemini, Molecular Devices, Sunnyvale, CA). The percentage of renin inhibition was calculated as follows:

$$
\begin{aligned}
\text { Renin inhibition }(\%)= & {\left[1-\Delta F I \min _{(\text {sample })}^{-1} / \Delta F I \min _{(\text {control })}^{-1}\right] } \\
& \times 100(\%)
\end{aligned}
$$

Where $\Delta \mathrm{FImin}^{-1}$ (sample) and $\Delta \mathrm{FImin}^{-1}$ (control) represent renin activity in the presence and absence of the peptides, respectively.

\section{Evaluation of antihypertensive activity of tilapia frame peptides in SHR0073}

Animal experiments were performed according to the protocol approved by the University of Manitoba Animal Protocols and Management Review Committee. Male spontaneously hypertensive rats (SHRs) were purchased at six weeks from Charles River (Montreal, PQ, Canada) and housed under a $12 \mathrm{~h}$ day and night cycle at $21^{\circ} \mathrm{C}$ and $50-55 \%$ humidity, with regular chow feed and tap water provided ad libitum. After one week acclimatization, SHRs were chronically implanted with Data Sciences International (DSI) HD-S10 telemetry transmitters (DSI, St. Paul, MN, USA), under anesthesia and analgesia, with all surgical procedures performed under sterile conditions. Rats were allowed two-week recovery period on ad libitum regular chow and water before oral gavage was performed. FPHPe-1 was dissolved in $1 \mathrm{~mL}$ of phosphate buffered saline (PBS) at a dose of $100 \mathrm{mg} / \mathrm{kg}$ body weight (BW) while captopril (an antihypertensive drug) was administered at a dose of $20 \mathrm{mg} / \mathrm{kg} \mathrm{BW}$, and the negative control rats received the saline solution only. Each group was orally gavaged with $1 \mathrm{~mL}$ of solution using a disposable plastic syringe. Real-time systolic and diastolic blood pressure (SBP and DBP) measurements, mean arterial pressure (MAP) and heart rates (HR) were collected in a quiet room with each rat cage placed on top of the receiver (Model RPC-1, DSI instruments, MN, USA) assigned to the implant. Data were recorded continuously at $10 \mathrm{~min}$ intervals for $24 \mathrm{~h}$ using Ponemah 6.1 data acquisition software (DSI instruments, MN, USA). An APR-1 atmospheric-pressure monitor (DSI instruments, MN, USA) was attached to the system to normalize the transmitted pressure values so that the recorded blood pressure signals were independent of atmospheric pressure changes. Results are reported as changes in values of the SBP, DBP, MAP and HR at 2, $4,6,8,12$ and $24 \mathrm{~h}$ minus their baseline measurements at time zero.

\section{Statistical analysis}

All experiments were conducted in triplicate and analyzed by one-way analysis of variance (ANOVA) followed by Tukey's multiple comparison test. The significance level of $p<0.05$ was employed. 


\section{Results and discussion}

\section{Characterization of enzymatic hydrolysates}

\section{Degree of hydrolysis (DH)}

During the enzymatic hydrolysis of FPI and SPI, the DH was measured at different time-points. During the first hour, the rate of pepsin and bromelain-catalysed FPI hydrolysis was higher than that of papain (Figure 1(a)). From 1-4 h, DH gradually increased at less rapid rates compared to the initial $30 \mathrm{~min}$. For SPI hydrolysis, pepsin (SPHPe) and papain hydrolysates (SPHPa) had similar pattern and there was no noticeable increase in $\mathrm{DH}$ values after 30 min with a maximum of $\sim 7 \%$. In contrast, the $\mathrm{DH}$ of bromelain hydrolysate (SPHBr) was higher than that of SPHPe and SPHPa after after $30 \mathrm{~min}$ of hydrolysis but did not exceed $\sim 10 \%$ (Figure 1(b)). Generally, the DH after $4 \mathrm{~h}$ was greater in frame hydrolysates (10-20\%) than the skin hydrolysates (lower than 10\%). The lower DH value for skin hydrolysates might be due to the triple-

\section{(a)}

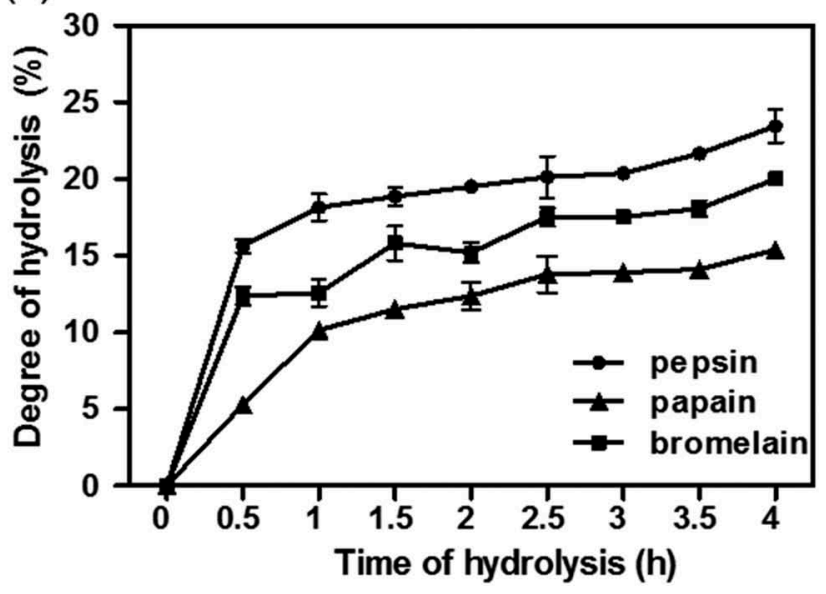

(b)

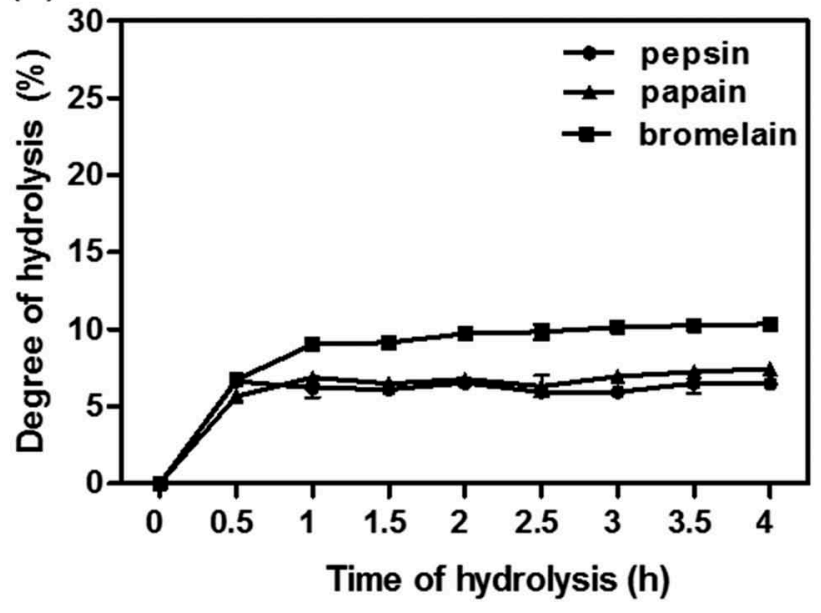

Figure 1. (a) Degree of hydrolysis (DH) of tilapia frame protein isolate (FPI) during enzymatic hydrolysis. (b) DH of tilapia skin protein isolate (SPI) during enzymatic hydrolysis. helical structure of collagen, which made SPI hard to cleave by the proteases except those belonging to the matrix metalloprotease (MMP) family like collagenases [30]. Collagen hydrolysates from other protein sources have been similarly characterized with low DH. For example, turkey head collagen hydrolysate produced using alcalase, flavourzyme or trypsin individually possessed fairly low DH values of $1-4 \%$ [31]. Even after subjecting the turkey collagen to dual-enzyme mixture or an enzyme cocktail comprising all the three proteases, the $\mathrm{DH}$ did not exceed $10 \%$.

$\mathrm{DH}$, yields and protein contents of tilapia enzymatic hydrolysates after $4 \mathrm{~h}$ hydrolysis are summarized in Table 1. The FPH produced by pepsin (FPHPe) and bromelain (FPHBr) possessed significantly higher $(p<0.05) \mathrm{DH}$, protein contents, and yields than papain-generated FPH (FPHPa). Moreover, the protein contents of FPHPe and FPHBr increased by about $10 \%$ compared to the FPI (PC: $75.35 \%$ ), which suggests that the hydrolysate production led to reduced solubilization of non-protein FPI materials. In contrast, SPHPe and SPHPa with lower DH showed higher protein contents than the SPHBr but the hydrolysates had similar protein contents as the SPI (79.16\%). There was no significant difference between the hydrolysate (SPHPe, SPHPa, and $\mathrm{SPHBr}$ ) yields obtained from SPH digestion.

\section{Protein/peptide patterns}

SDS-PAGE analysis was carried out to visualize the protein/peptide patterns of FPI, SPI, FPHs (FPHPe, FPHPa, and FPHBr), and SPHs (SPHPe, SPHPa, and $\mathrm{SPHBr}$ ) (Figure 2). Multiple bands higher than $10 \mathrm{kDa}$ were displayed in lane A (FPI) with much more intense bands from 37 to $250 \mathrm{kDa}$. According to the result of tilapia protein identification from FPI using proteomic strategy [2], the $37-50 \mathrm{kDa}$ band in lane A may be related to $\alpha$-actin $(39.3 \mathrm{kDa})$ while myosin heavy chain $(173.3 \mathrm{kDa})$ may appear in the $150-250 \mathrm{kDa}$ band. Protein bands with MWs above $37 \mathrm{kDa}$ were not observed in the lanes of FPHs (lane B, C and D), which suggests the degradation of identified proteins in FPI. Two obvious bands above $100 \mathrm{kDa}$ in lane $\mathrm{E}$ may be related to different chain types of SPI collagen. The $100-150 \mathrm{kDa}$ band could be collagen alpha-1(2) as we have previously identified [2].

Most peptides shown in lane B, C and D were lower than $10 \mathrm{kDa}$, which is consistent with extensive protein hydrolysis. In lane B, bands corresponding to MWs of myosin and actin disappeared, replaced by two distinct bands of MW around $25-37 \mathrm{kDa}$ and a group of smaller peptides lower than $10 \mathrm{kDa}$. The polypeptide patterns of flaxseed protein hydrolysates reported by Karama'c et al. [32] also demonstrated that the 
Table 1. Degree of hydrolysis $(\mathrm{DH})$, protein content and yields of tilapia frame and skin protein hydrolysates after 4-h hydrolysis.

\begin{tabular}{|c|c|c|c|c|}
\hline Samples & $\begin{array}{l}\text { Enzyme } \\
\left(E / S^{a}: 1 \%\right)\end{array}$ & $\begin{array}{c}\text { Degree of } \\
\text { Hydrolysis } \\
(\%)\end{array}$ & $\begin{array}{c}\text { Protein content } \\
(\%)\end{array}$ & $\begin{array}{l}\text { Yield }^{\mathrm{b}} \\
(\%)\end{array}$ \\
\hline Frame protein & Pepsin (FPHPe) & $23.46 \pm 1.08^{\mathrm{a}}$ & $84.93 \pm 1.01^{\mathrm{a}}$ & $80.66 \pm 6.83^{a}$ \\
\hline hydrolysates & Papain (FPHPa) & $15.38 \pm 0.04^{c}$ & $68.88 \pm 5.36^{b}$ & $56.42 \pm 14.03^{b}$ \\
\hline (FPHs) & Bromelain ( $\mathrm{FPHBr}$ ) & $20.01 \pm 0.22^{b}$ & $89.05 \pm 1.10^{a}$ & $67.85 \pm 0.78^{\mathrm{a}}$ \\
\hline Skin protein & Pepsin (SPHPe) & $6.48 \pm 0.10^{\mathrm{e}}$ & $79.51 \pm 8.37^{a}$ & $105.14 \pm 14.09^{a}$ \\
\hline hydrolysates & Papain (SPHPa) & $7.44 \pm 0.20^{\mathrm{e}}$ & $81.43 \pm 3.33^{a}$ & $81.25 \pm 17.47^{a}$ \\
\hline (SPHs) & Bromelain (SPHBr) & $10.33 \pm 0.15^{d}$ & $68.21 \pm 2.80^{b}$ & $92.39 \pm 0.40^{\mathrm{a}}$ \\
\hline
\end{tabular}

${ }^{\mathrm{a}} \mathrm{E} / \mathrm{S}$ : the ratio of the weights of enzymes against substrates.

${ }^{\mathrm{b}}$ The yield was calculated based on the dry weight of resultant hydrolysate against the dry weight of protein isolate used for hydrolysis.

Results are presented as mean \pm standard deviation with triplicate measurements. For each column, values that contain different letters are significantly different at $p<0.05$.

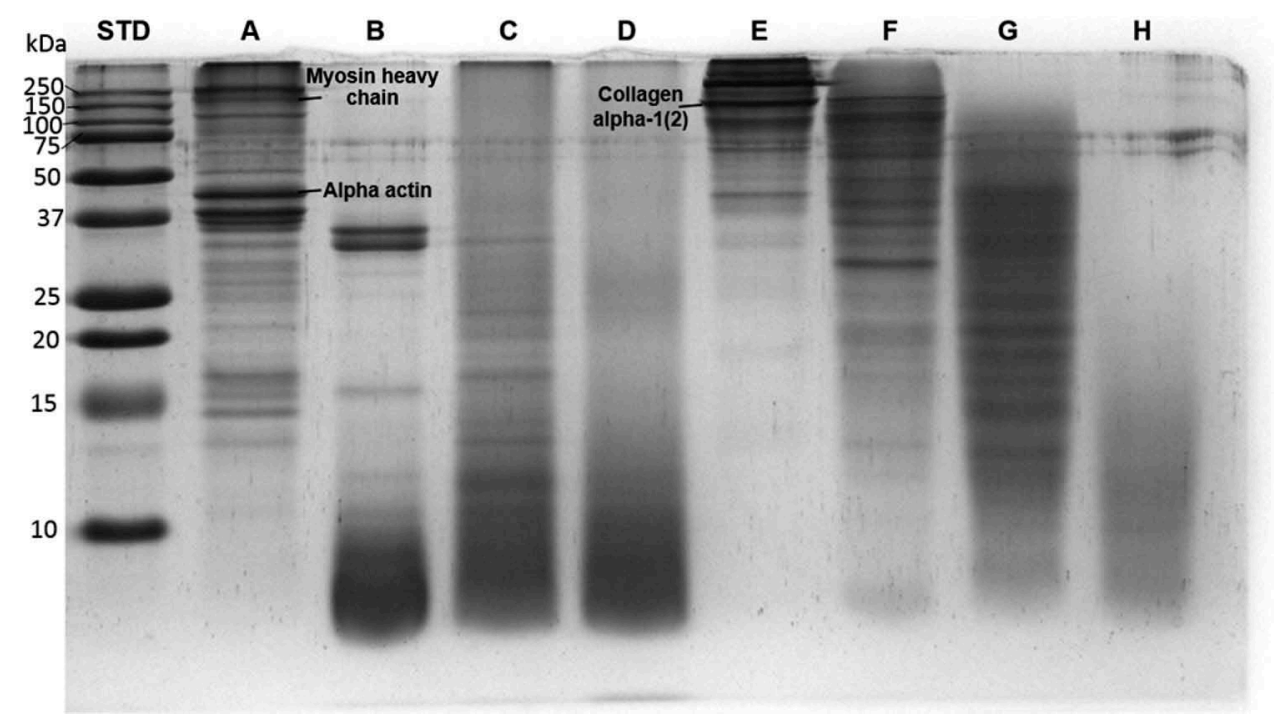

Figure 2. SDS-PAGE of samples from tilapia frame protein isolate (FPI, lane A), frame protein hydrolysates generated by pepsin (FPHPe, lane B), papain (FPHPa, lane C) and bromelain ( $\mathrm{FPHBr}$, lane D), skin protein isolate (SPI, lane E), and skin protein hydrolysates generated by pepsin (SPHPe, lane F), papain (SPHPa, lane G) and bromelain (SPHBr, lane H).

enzymatic treatment resulted in the degradation of major proteins in flaxseeds. SPHPe (lane F) mainly consisted of peptides larger than $25 \mathrm{kDa}$ while the MWs of SPHPa (lane G) ranged from 10 to $50 \mathrm{kDa}$. Protein band patterns of FPHs and SPHs were strongly related to the DH. FPHPe (lane B) with the highest DH seemed to contain the highest amount of low MW (< $10 \mathrm{kDa}$ ) peptides. A similar trend occurred in the protein hydrolysates of red tilapia (Oreochromis niloticus) fillet that as $\mathrm{DH}$ increased with time, peptide bands with MWs lower than $14.4 \mathrm{kDa}$ became more obvious [23].

\section{Prediction of bioactive peptides derived from identified proteins by BIOPEP analysis}

In the BIOPEP database, the frequency of bioactive fragments (A) in a protein chain equals the number of fragments with a given activity (a) within the protein divided by the number of amino acid residues (N) within this protein $(A=a / N)$ [13]. The frequency of ACE-inhibitory peptides in SPI-derived collagen alpha1(I) and collagen alpha-2(I) was 0.722 and 0.756 , respectively. The frequency of peptides with the ACEinhibitory activity was $0.350-0.414$ in the proteins (myosin heavy chain, troponin $\mathrm{T}$, creatine kinase, fructose-bisphosphate aldolase $\mathrm{A}$ and alpha actin) identified from FPI [2]. Accordingly, SPI might be a more excellent protein source of ACE-inhibitory peptides than FPI based on the in silico study.

Since encrypted peptides need to be released from precursor protein to possess activities, simulation of enzymatic digestion of FPI and SPI protein sequences using BIOPEP's enzyme action tool was conducted. The numbers of ACE-inhibitory peptides liberated by pepsin, papain, bromelain, and a combination of digestive enzymes (pepsin, trypsin, and chymotrypsin A or C) are displayed in Table 2. In addition, the sequences as well as the number of each kind of ACE-inhibitory peptide potentially released are also summarized in the 
Table 2. Number of predictive angiotensin converting enzyme (ACE)-inhibitory peptides released from identified tilapia (a) frame proteins and (b) skin proteins using BIOPEP's enzyme action tool.

\begin{tabular}{|c|c|c|c|c|c|}
\hline (a) & Alpha actin* & Myosin heavy chain $^{a_{1 *}}$ & Creatine kinase $^{b_{\text {, } *}}$ & Troponin $\mathrm{T}^{*}$ & $\begin{array}{c}\text { Fructose-bisphosphate } \\
\text { aldolase } A^{*}\end{array}$ \\
\hline Pepsin & 13 & 68 & 16 & 21 & 11 \\
\hline Papain & 18 & 61 & 18 & 15 & 13 \\
\hline Bromelain & 12 & 38 & 5 & 5 & 10 \\
\hline $\begin{array}{l}\text { Pepsin+Trypsin+ } \\
\text { Chymotrypsin A }\end{array}$ & 18 & 76 & 24 & 18 & 10 \\
\hline $\begin{array}{l}\text { Pepsin+Trypsin+ } \\
\text { Chymotrypsin C }\end{array}$ & 22 & 78 & 27 & 16 & 11 \\
\hline (b) & \multicolumn{4}{|c|}{ Collagen alpha- $1(\mathrm{I})$ chain $^{\mathrm{c}, *}$} & Collagen alpha-2(I) chain $^{\mathrm{d}, *}$ \\
\hline Pepsin & \multicolumn{4}{|c|}{54} & 51 \\
\hline Papain & \multicolumn{4}{|c|}{129} & 121 \\
\hline Bromelain & \multicolumn{3}{|c|}{97} & & 85 \\
\hline $\begin{array}{l}\text { Pepsin+Trypsin+ } \\
\text { Chymotrypsin A }\end{array}$ & \multicolumn{3}{|c|}{104} & & 96 \\
\hline $\begin{array}{l}\text { Pepsin+Trypsin+ } \\
\text { Chymotrypsin C }\end{array}$ & \multicolumn{3}{|c|}{221} & & 214 \\
\hline
\end{tabular}

${ }^{a}$ Myosin heavy chain, fast skeletal muscle-like.

${ }^{\mathrm{b}}$ Creatine kinase M-type-like.

cCollagen alpha-1(I) chain-like isoformX2.

${ }^{\mathrm{d}}$ Collagen alpha-2(I) chain-like isoformX1.

*Protein sequences of the tilapia skin proteins shown in this table were all identified in our previous study [2].

supplementary data (Table S1). The in silico results suggest that pepsin and papain released more ACEinhibitory peptides from FPI than bromelain (Table 2 (a)). On the other hand, in silico digestion of SPI by papain generated 129 and 121 ACE-inhibitory peptides, which were more than the numbers released by pepsin (54 and 51) and bromelain (97 and 85) (Table 2 (b)). Although computer aided simulation is a useful research tool for choosing the most appropriate enzymes, actual in vitro or in vivo experiments are still necessary because external factors may be involved during protein hydrolysis, which limits utility of the in silico methods.

\section{In vitro ACE inhibitory activity of FPH and SPH}

The ACE-inhibitory activity of hydrolysates was evaluated and results showed that all FPHs exhibited significantly stronger activity $(p<0.05)$ than SPHs (Figure 3(a)). Captopril almost completely inhibited ACE activity (99.3\%) while FPHPe with the highest DH revealed $79.7 \%$ ACE-inhibitory activity at the same $1 \mathrm{mg} / \mathrm{mL}$ concentration. Correspondingly, there was a significant linear relationship between the $\mathrm{DH}$ and the ACE inhibitory activity (Figure 3(b)). Based on the in silico result in Table 2(b), FPHPa seemed to have greater activity than FPHBr because of more ACEinhibitory peptides released. However, there was no significant difference $(p>0.05)$ between the in vitro inhibitory properties of these two hydrolysates. This might be due to the relatively lower DH of FPHPa causing a restricted liberation of the ACE-inhibitory peptides. Similarly, SPHBr with higher $\mathrm{DH}$ than
SPHPe and SPHPa also showed stronger ACE-inhibitory activity (39\%). Previous research indicated Cryotin-F and Flavourzyme hydrolysates of tilapia fillet with the $25 \% \mathrm{DH}$ possessed greater ACE-inhibitory activity than those with the $\mathrm{DH}$ value of $7.5 \%$ [7]. Thus, it was likely that ACE-inhibitory activity observed for FPHs and SPHs was determined mostly by their peptide size.

The $\mathrm{IC}_{50}$ value of FPHPe was $0.57 \mathrm{mg} / \mathrm{mL}$, which was similar to the $\mathrm{IC}_{50}$ value of pepsin-catalyzed krill (Euphausia superba) protein hydrolysate $(0.58 \mathrm{mg} / \mathrm{mL})$ [33] but lower than that of $<5 \mathrm{kDa}$ chymotrypsin hydrolysate from yellowfin sole (Limanda aspera) frame $(0.88 \mathrm{mg} / \mathrm{mL})$ [34]; the ACE-inhibitory activity of FPHPe was also stronger than the pepsin hydrolysate from sea squirt (Styela plicata) $\left(\mathrm{IC}_{50}: 2.43 \mathrm{mg} / \mathrm{mL}\right.$ ) [35]. On the other hand, while SPHs showed weaker ACE inhibition effects, hydrolysis by serial protease-treatments may be a feasible way to overcome this obstacle. This was illustrated by the following sequential hydrolysis of Alaska Pollack skin gelatin extracts using alcalase, pronase $\mathrm{E}$, and collagenase in a three-step recycling membrane reactor, which produced ACE-inhibitory hydrolysate with a low $\mathrm{IC}_{50}$ value of $0.63 \mathrm{mg} / \mathrm{mL}$ [36]. The $0.63 \mathrm{mg} / \mathrm{mL}$ value is twice as potent as the single enzyme hydrolysate $\left(\mathrm{IC}_{50}: 1.4 \mathrm{mg} / \mathrm{mL}\right)$.

\section{ACE and renin inhibitory activities of peptide fractions from FPHPe}

The ultrafiltration system using 1-10 kDa MWCO membranes is usually applied to separate bioactive peptides into fractions with different molecular weights 
(a)

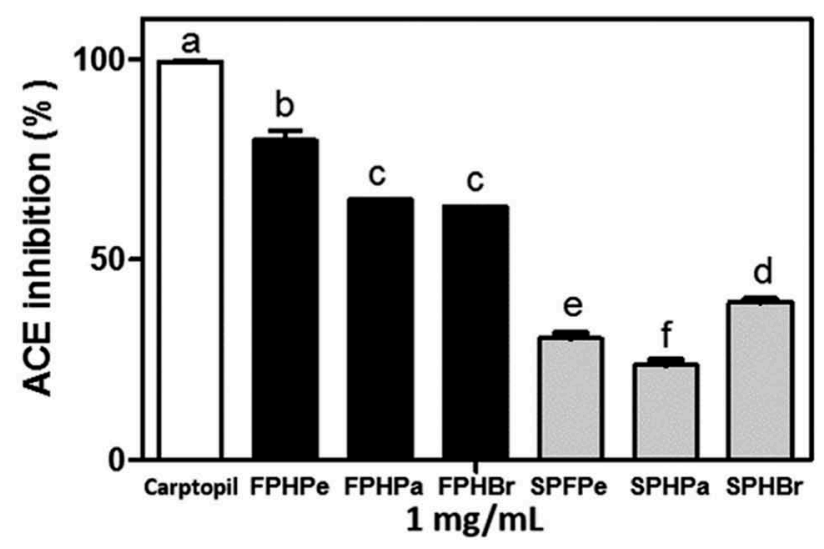

(b)

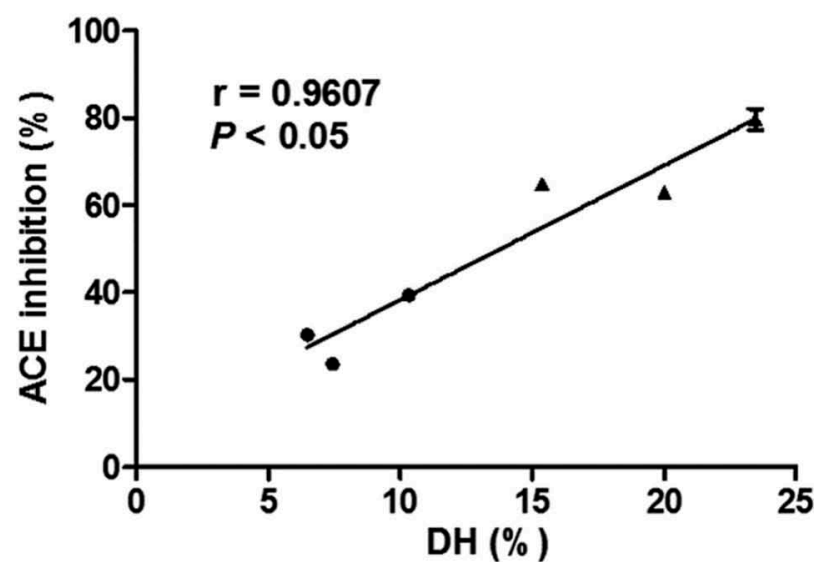

Figure 3. (a) In vitro Angiotensin-I converting enzyme (ACE) inhibitory activities of frame protein hydrolysates (FPHs: FPHPe, $\mathrm{FPHPa}$, and $\mathrm{FPHBr}$ ) and skin protein hydrolysates (SPHs: SPHPe, $\mathrm{SPHPa}$, and $\mathrm{SPHBr}$ ) generated by pepsin, papain, or bromelain. Bars with different letters are significantly different $(p<0.05)$. (b) The correlation plot between degree of hydrolysis $(\mathrm{DH})$ and

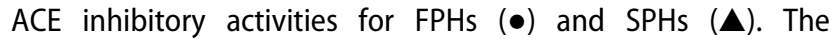
Pearson's $r$ value is 0.9607 and $p<0.05$ represents the correlation is significant.

[37,38]. This is because the size of ACE-inhibitory peptides is generally between 2 and 30 amino acids [39]. FPHPe was selected for further purification using an ultrafiltration system because it exhibited superior ACE-inhibitory activity among the FPHs and SPHs. According to the outcome of BIOPEP analysis, more than $70 \%$ of the ACE-inhibitory peptides from pepsin-hydrolyzed frame proteins were dipeptides and $\sim 18 \%$ were tripeptides. The protein contents of $<1 \mathrm{kDa}$, 1-3 $\mathrm{kDa}$, and 3-5 $\mathrm{kDa}$ hydrolysate fractions were 91.47\%, 91.39\%, and 97.19\%, respectively, which were all higher than FPI and FPHPe. Both protein content $(86.42 \%)$ and yield $(2.78 \%)$ of $5-10 \mathrm{kDa}$ hydrolysate fraction were the lowest compared to other fractions. The yields of $<1 \mathrm{kDa}, 1-3 \mathrm{kDa}$, and $3-5 \mathrm{kDa}$ hydrolysate fractions were $7.63 \%, 14.85 \%$, and $7.42 \%$, respectively.

Results of the ACE inhibition assay revealed that the $<1 \mathrm{kDa}$ ultrafiltration fraction from FPHPe (FPHPe1) showed the strongest inhibitory effect on ACE activity while the potency decreased as the MWs of peptides increased (Figure $4(\mathrm{a})$ ). The $\mathrm{IC}_{50}$ values of $<1 \mathrm{kDa}, 1-3$ $\mathrm{kDa}, 3-5 \mathrm{kDa}$, and $5-10 \mathrm{kDa}$ fractions were $0.41 \mathrm{mg} /$ $\mathrm{mL}, \quad 0.55 \mathrm{mg} / \mathrm{mL}, \quad 0.79 \mathrm{mg} / \mathrm{mL}$, and $0.83 \mathrm{mg} / \mathrm{mL}$, respectively. The $\mathrm{IC}_{50}$ value of $\mathrm{FPHPe} 1$ was similar to $0.46 \mathrm{mg} / \mathrm{mL}$ reported for the Alaska pollack frame $<1$ $\mathrm{kDa}$ protein hydrolysate [40], but higher than the $0.19 \mathrm{mg} / \mathrm{mL}$ for krill [33]. With respect to renin inhibitory activity, FPHPe1 had considerably higher $(p<0.05)$ inhibitory effect $(54.28 \%)$ than the larger peptide sizes at $1 \mathrm{mg} / \mathrm{mL}$ concentration (Figure 4(b)). The hydrolysates from kidney bean protein [41] and bovine hemoglobin [42] displayed a similar trend. Since FPHPe1 showed a better capacity to inhibit both ACE and renin activities than the other fractions,

(a)

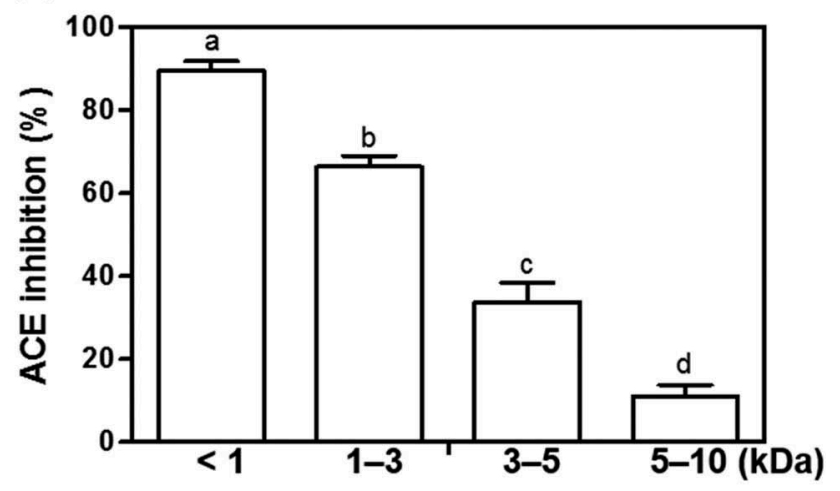

(b)

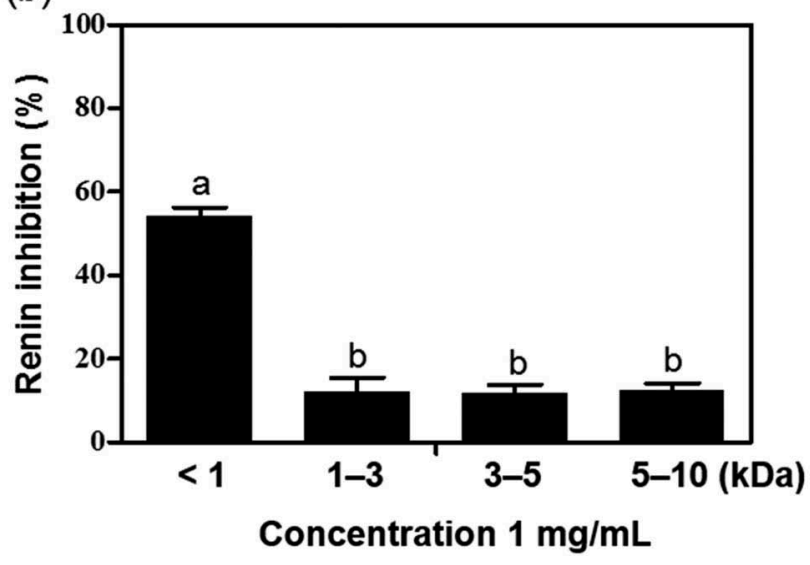

Figure 4. (a) In vitro angiotensin-I converting enzyme (ACE) inhibitory activities of the ultrafiltration fractions of pepsinhydrolyzed frame protein hydrolysate (FPHPe) at of $0.6 \mathrm{mg} /$ $\mathrm{mL}$. (b) In vitro renin inhibitory activities of the fractions from FPHPe at of $1 \mathrm{mg} / \mathrm{mL}$. Bars with different letters have significantly $(p<0.05)$ different mean values. 
the hypotensive effect of this peptide fraction in SHR was subsequently investigated.

\section{Antihypertensive effect of FPHPe1 in SHR}

The peptides must be intact and absorbed through the intestine and reach the target enzymes in an active form to produce antihypertensive effects in vivo. Short peptides consisting of two or three amino acids are absorbed more quickly than free amino acids [43]. Although larger peptides (10-15 amino acids) can also be absorbed through the intestine to generate biological effects, the potency of the peptide decreases as the chain length increases [44]. After in vivo hydrolysis, the numbers and sequences of bioactive peptides may change due to further cleavage of digestive enzymes, resulting in the enhancement or loss of activities. The numbers of pepsin-generated ACE-inhibitory peptides from alpha-actin, myosin heavy chain, and creatine kinase increased when the in silico digestion was conducted along with trypsin and chymotrypsin (Table 2 (a)), which simulated gastrointestinal tract digestion. Additionally, under the simultaneous actions of trypsin and chymotrypsin the renin inhibitor $\mathrm{KF}\left(\mathrm{EC}_{50}\right.$ : $17.84 \mu \mathrm{M})$ from pepsin-digested myosin and troponin
$\mathrm{T}$ was supplemented by the other renin inhibitory peptide IR, which possesses lower IC $_{50}$ value $(9.2 \mu \mathrm{M})$.

The antihypertensive effect of FPHPe1 was evaluated based on the changes in physiological parameters of hypertension including SBP, DBP, MAP and HR after oral administration to SHRs. Figure 5 shows that the saline solution was ineffective reducing SBP, DBP, and MAP of SHRs during the $24 \mathrm{~h}$ after administration, whereas the FPHPe1 showed fast-acting effects in SHRs. The maximal reduction of SBP, DBP, and MAP caused by FPHPel appeared after $2 \mathrm{~h}$, which was $-33,-24$, and $-28 \mathrm{~mm} \mathrm{Hg}$, respectively. The decrease of HR also happened with a maximum reduction of 58 beats per min after $4 \mathrm{~h}$. On account of no significant difference $(p>0.05)$ between the changes in SBP, DBP, and MAP at different timepoints after oral gavage with peptides, FPHPe1 was considered to provide a rapid and persistent antihypertensive effect in SHRs. Furthermore, the in vivo antihypertensive property of FPHPe1 at $100 \mathrm{mg} / \mathrm{kg} \mathrm{BW}$ was quite identical to the hypotensive effect in SHRs treated with captopril $(20 \mathrm{mg} / \mathrm{kg}$ BW) as changes of SBP, MAP and HR in SHRs did not show a significant difference $(p>0.05)$. The positive result of the rat study has established that the active FPHPel peptides may have survived gastrointestinal digestion or were hydrolyzed to give other (a)

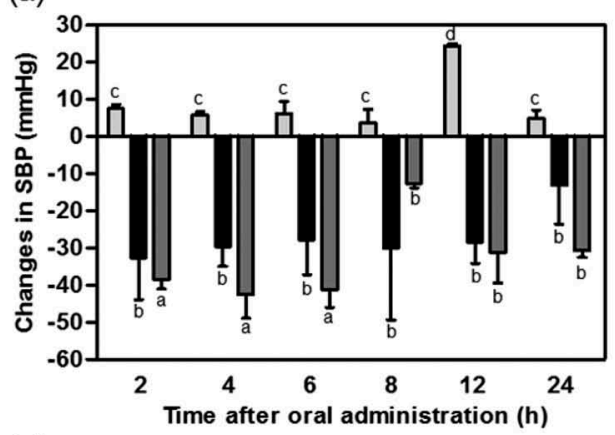

(c)

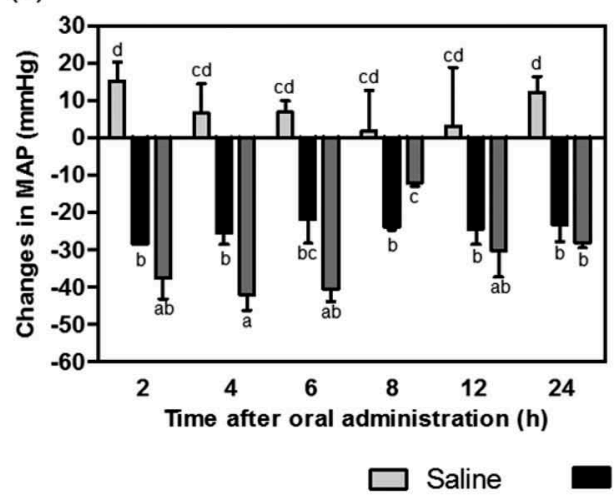

(b)

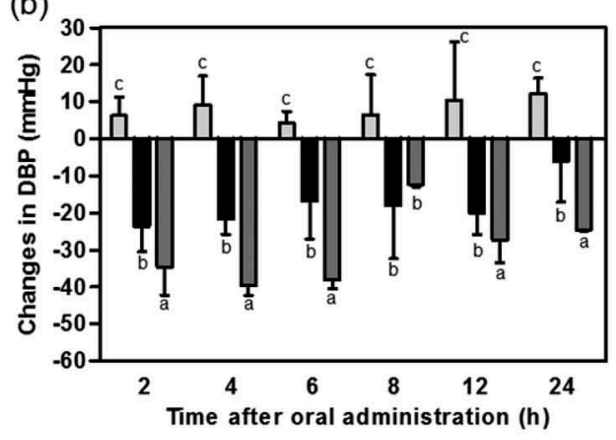

(d)

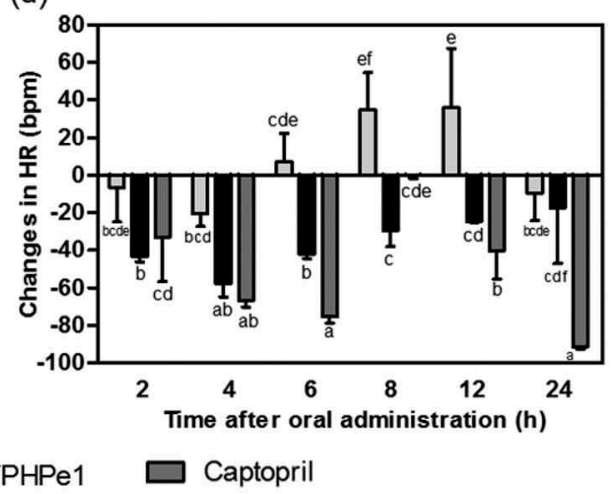

Figure 5. The effect of the $<1 \mathrm{kDa}$ ultrafiltration fraction from pepsin-hydrolyzed frame protein hydrolysate (FPHPe1) on (a) systolic blood pressure (SBP), (b) diastolic blood pressure (DBP), (c) mean arterial pressure (MAP), and (d) heart rate (HR) of spontaneously hypertensive rats (SHRs) after oral gavage. Different letters above the bars indicate significant differences $(p<0.05)$. 
active sequences, all of which contributed to the excellent blood pressure-lowering effects in SHRs.

\section{Conclusions}

Protein hydrolysates prepared from tilapia coproducts including frame and skin demonstrated varying degrees of in vitro inhibitory activities against renin and ACE. FPHs with higher DH showed stronger in vitro ACEinhibitory effect than SPHs even though in silico proteolysis suggested a higher number of ACE-inhibitory peptides in the latter. Fraction FPHPel $(<1 \mathrm{kDa})$ exhibited greater ACE and renin inhibitory activities, which is consistent with the fact that most bioactive peptide sequences identified within tilapia protein sequences in the BIOPEP database are less than $1 \mathrm{kDa}$. The rapid reduction in blood pressure and the long duration of the antihypertensive effect exhibited by FPHPel in SHRs indicate that the protein hydrolysate from tilapia frame was able to develop into a promising ingredient for the formulation of antihypertensive functional foods or nutraceuticals. However, various factors such as the $\mathrm{DH}$, diverse $\mathrm{IC}_{50}$ values, and the unavailability of peptide information in databases could have contributed to the observed inconsistency between experimental and theoretical (in silico) results. This study has demonstrated that proteomics strategies for protein identification coupled with BIOPEP analysis of potential bioactive peptides is a feasible way to select appropriate protein sources or enzymes when producing bioactive peptides.

\section{Acknowledgments}

The authors are grateful for the financial support provided by Ministry of Science and Technology of Taiwan (MOST: 104-2311-B-019-002/105-2311-B-019-002). We would also like to express our gratitude to the members of R.E Aluko's laboratory for their comments and technical assistance during the course of this research. R. E. Aluko's research program is funded by the Natural Sciences and Engineering Research Council of Canada (NSERC).

\section{Disclosure statement}

No potential conflict of interest was reported by the authors.

\section{Funding}

This work was supported by the Ministry of Science and Technology, Taiwan [104-2311-B-019-002/105-2311-B-019002];Natural Sciences and Engineering Research Council of Canada;

\section{ORCID}

Adeola M. Alashi (DD http://orcid.org/0000-0002-9223-0529

Rotimi E. Aluko (D) http://orcid.org/0000-0002-9025-2513

\section{References}

[1] FAO. Yearbook of fishery and aquaculture statistics 2014: world aquaculture production by species groups. United Nations: FAO; 2016.

[2] Huang -B-B, Lin H-C, Chang Y-W. Analysis of proteins and potential bioactive peptides from tilapia (Oreochromis spp.) processing co-products using proteomic techniques coupled with BIOPEP database. J Funct Foods. 2015;19:Part A:629-640.

[3] Stevanato FB, Almeida VV, Matsushita M, et al. Fatty acids and nutrients in the flour made from tilapia (Oreochromis niloticus) heads. Food Sci Technol (Campinas). 2008;28:440-443.

[4] Muzaifa M, Safriani N, Zakaria F. Production of protein hydrolysates from fish by-product prepared by enzymatic hydrolysis. Int J Bioflux Soc. 2012;5:36-39.

[5] Yarnpakdee S, Benjakul S, Kristinsson HG, et al. Antioxidant and sensory properties of protein hydrolysate derived from Nile tilapia (Oreochromis niloticus) by one- and two-step hydrolysis. J Food Sci Technol. 2015;52:3336-3349.

[6] Foh MBK, Amadou I, Foh BM, et al. Functionality and antioxidant properties of tilapia (Oreochromis niloticus) as influenced by the degree of hydrolysis. Int J Mol Sci. 2010;11:1851-1869.

[7] Raghavan S, Kristinsson HG. ACE-inhibitory activity of tilapia protein hydrolysates. Food Chem. 2009;117:582-588.

[8] Yarnpakdee S, Benjakul S, Kristinsson HG, et al. Preventive effect of Nile tilapia hydrolysate against oxidative damage of HepG2 cells and DNA mediated by $\mathrm{H} 2 \mathrm{O} 2$ and AAPH. J Food Sci Technol. 2015;52:6194-6205.

[9] Chuesiang P, Sanguandeekul R. Protein hydrolysate from tilapia frame: antioxidant and angiotensin I converting enzyme inhibitor properties. Int J Food Sci Tech. 2015;50:1436-1444.

[10] Choonpicharn S, Jaturasitha S, Rakariyatham N, et al. Antioxidant and antihypertensive activity of gelatin hydrolysate from Nile tilapia skin. J Food Sci Technol. 2015;52:3134-3139.

[11] Robert M, Zatylny-Gaudin C, Fournier V, et al. Molecular characterization of peptide fractions of a tilapia (Oreochromis niloticus) by-product hydrolysate and in vitro evaluation of antibacterial activity. Process Biochem. 2015;50:487-492.

[12] Chen $\mathrm{D}, \mathrm{Mu} \mathrm{X}$, Huang $\mathrm{H}$, et al. Isolation of a calciumbinding peptide from tilapia scale protein hydrolysate and its calcium bioavailability in rats. J Funct Foods. 2014;6:575-584.

[13] Minkiewicz P, Dziuba J, Iwaniak A, et al. BIOPEP database and other programs for processing bioactive peptide sequences. J AOAC Int. 2008;91:965-980.

[14] Chang Y-W, Alli I. In silico assessment: suggested homology of chickpea (Cicer arietinum L.) legumin and prediction of ACE-inhibitory peptides from chickpea proteins using BLAST and BIOPEP analyses. Food Res Int. 2012;49:477-486. 
[15] Gangopadhyay N, Wynne K, O’Connor P, et al. In silico and in vitro analyses of the angiotensin-I converting enzyme inhibitory activity of hydrolysates generated from crude barley (Hordeum vulgare) protein concentrates. Food Chem. 2016;203:367-374.

[16] Chatterjee A, Kanawjia SK, Khetra Y, et al. Discordance between in silico \& in vitro analyses of ACE inhibitory \& antioxidative peptides from mixed milk tryptic whey protein hydrolysate. J Food Sci Technol. 2015;52:5621-5630.

[17] Lafarga T, O’Connor P, Hayes M. In silico methods to identify meat-derived prolyl endopeptidase inhibitors. Food Chem. 2015;175:337-343.

[18] Ibrahim MM. RAS inhibition in hypertension. J Hum Hypertens. 2006;20:101-108.

[19] He R, Aluko RE, Ju XR. Evaluating molecular mechanism of hypotensive peptides interactions with renin and angiotensin converting enzyme. PLoS One. 2014;9:e91051.

[20] Fu Y, Young JF, Løkke MM, et al. Revalorisation of bovine collagen as a potential precursor of angiotensin I-converting enzyme (ACE) inhibitory peptides based on in silico and in vitro protein digestions. J Funct Foods. 2016;24:196-206.

[21] Zhang X, Ookawa M, Tan Y, et al. Biochemical characterisation and assessment of fibril-forming ability of collagens extracted from Bester sturgeon Huso huso $\times$ Acipenser ruthenus. Food Chem. 2014;160:305-312.

[22] BIOPEP database. [cited 2016 Dec 29]. Available from: http://www.uwm.edu.pl/biochemia/index.php/pl/biopep

[23] Shamloo M, Bakar J, Mat Hashim D, et al. Biochemical properties of red tilapia (Oreochromis niloticus) protein hydrolysates. Int Food Res J. 2012;19:183-188.

[24] Markwell MAK, Haas SM, Bieber LL, et al. A modification of the Lowry procedure to simplify protein determination in membrane and lipoprotein samples. Anal Biochem. 1978;87:206-210.

[25] Charoenphun N, Cheirsilp B, Sirinupong N, et al. Calcium-binding peptides derived from tilapia (Oreochromis niloticus) protein hydrolysate. Eur Food Res Technol. 2013;236:57-63.

[26] Laemmli UK. Cleavage of structural proteins during the assembly of the head of bacteriophage T4. Nature. 1970;227:680-685.

[27] Alashi AM, Blanchard CL, Mailer RJ, et al. Blood pressure lowering effects of Australian canola protein hydrolysates in spontaneously hypertensive rats. Food Res Int. 2014;55:281-287.

[28] Udenigwe CC, Lin Y-S, Hou W-C, et al. Kinetics of the inhibition of renin and angiotensin I-converting enzyme by flaxseed protein hydrolysate fractions. J Funct Foods. 2009;1:199-207.

[29] Girgih AT, Udenigwe CC, Li H, et al. Kinetics of enzyme inhibition and antihypertensive effects of hemp seed (Cannabis sativa L.) protein hydrolysates. J Am Oil Chem Soc. 2011;88:1767-1774.

[30] Chung L, Dinakarpandian D, Yoshida N, et al. Collagenase unwinds triple-helical collagen prior to peptide bond hydrolysis. EMBO J. 2004;23:3020-3030.
[31] Khiari Z, Ndagijimana M, Betti M. Low molecular weight bioactive peptides derived from the enzymatic hydrolysis of collagen after isoelectric solubilization/ precipitation process of turkey by-products. Poult Sci. 2014;93:2347-2362.

[32] Karamac M, Kosinska-Cagnazzo A, Kulczyk A. Use of different proteases to obtain flaxseed protein hydrolysates with antioxidant activity. Int J Mol Sci. 2016;17:1027.

[33] Park SY, Je J-Y, Ahn C-B. Protein hydrolysates and ultrafiltration fractions obtained from Krill (Euphausia superba): nutritional, functional, antioxidant, and ACEInhibitory characterization. J Aquat Food Prod Technol. 2016;25:1266-1277.

[34] Jung W-K, Mendis E, Je J-Y, et al. Angiotensin I-converting enzyme inhibitory peptide from yellowfin sole (Limanda aspera) frame protein and its antihypertensive effect in spontaneously hypertensive rats. Food Chem. 2006;94:26-32.

[35] Ko S-C, Kang MC, Lee J-K, et al. Effect of angiotensin I-converting enzyme (ACE) inhibitory peptide purified from enzymatic hydrolysates of Styela plicata. Eur Food Res Technol. 2011;233:915-922.

[36] Byun H-G, Kim S-K. Purification and characterization of angiotensin I converting enzyme (ACE) inhibitory peptides from Alaska pollack (Theragra chalcogramma) skin. Process Biochem. 2001;36:1155-1162.

[37] Doyen A, Beaulieu L, Saucier L, et al. Impact of ultrafiltration membrane material on peptide separation from a snow crab byproduct hydrolysate by electrodialysis with ultrafiltration membranes. J Agric Food Chem. 2011;59:1784-1792.

[38] Lemes AC, Sala L, Ores Jda C, et al. A review of the latest advances in encrypted bioactive peptides from protein-rich waste. Int J Mol Sci. 2016;17:950.

[39] Erdmann K, Cheung BW, Schroder H. The possible roles of food-derived bioactive peptides in reducing the risk of cardiovascular disease. J Nutr Biochem. 2008;19:643-654.

[40] Je JY, Park PJ, Kwon JY, et al. A novel angiotensin I converting enzyme inhibitory peptide from Alaska pollack (Theragra chalcogramma) frame protein hydrolysate. J Agric Food Chem. 2004;52:7842-7845.

[41] Mundi S, Aluko RE. Inhibitory properties of kidney bean protein hydrolysate and its membrane fractions against renin, angiotensin converting enzyme, and free radicals. Austin J Nutr Food Sci. 2014;2:1008.

[42] Lafarga T, Rai DK, O'Connor P, et al. Generation of bioactive hydrolysates and peptides from bovine hemoglobin with in vitro renin, angiotensin-I-converting enzyme and dipeptidyl peptidase-IV inhibitory activities. J Food Biochem. 2016;40:673-685.

[43] Webb KE Jr. Intestinal absorption of protein hydrolysis products: a review. J Anim Sci. 1990;68:3011-3022.

[44] Roberts PR, Burney JD, Black KW, et al. Effect of chain length on absorption of biologically active peptides from the gastrointestinal tract. Digestion. 1999;60:332-337. 